\title{
Analysis of Thematic Prominence in Selected Nigerian Inaugural Political Speeches
}

\author{
Chinwe R. Ezeifeka \\ http://dx.doi.org//10.4314/ujah.v17i2.2
}

\section{Abstract}

The paper analyses the thematic structure of two inaugural speeches of Nigerian past leaders using Halliday and Matthiessen's formulation of the lexicogrammatical feature of Theme located in the textual metafunction in systemic functional grammar. It specifically focuses on the speakers' strategies of fronting certain lexical items clause-initially to construe certain meanings in favour of others. For instance, the choice of unmarked theme where the subject conflates with the theme are more prevalent in utterances where the speakers would want to take credit for positive actions and audience acknowledgement, or where they would want to assign modal responsibility to their audience for negative actions, while marked theme seem to feature more in cases that are indeterminate, illusive and less than likely to be realizable goals. These choices serve as ideological tools aimed at legitimating the hegemonies of the power elite in order to manufacture the consent of their electorate. The work concludes that the textual metafunction realized in the lexicogrammatical feature of Theme serve as a resource for speakers to manipulate meanings to suit their ideological ends and calls for critical language awareness which locates the work within the critical discourse analysis (CDA) research paradigm.

Keywords: Theme, textual metafunction, critical discourse analysis, power, ideology, critical language awareness, topical theme, marked theme, unmarked theme. 


\section{Introduction}

Our words are never neutral. They convey how we see ourselves as a profession, our identity, knowledge, values and beliefs and our truths. Our discourse permeates everything we do" (Ruth Wodak)

The importance of political speeches as a plan of action for a nation's future calls attention to the linguistic choices made in such speeches and the need for a critical language awareness of the implications of such linguistic choices. The paper was motivated by the seemingly selective prominence given to some linguistic choices in subject and topical theme positions in the textual data that are the focus of this paper. It is an established fact that linguistic choices in spoken and written texts are not arbitrary or neutral, they are conditioned by the position of the speaker/writer, the intentions s/he wants to express and the ideologies inherent in the propositions and proposals (Wodak, 2004). The quotation at the beginning of this paper gives credence to the above thesis and this is what this paper sets out to explore. The vast rhetorical potentials of linguistic choices which speakers can exploit to achieve their individual and group purposes is at the crux of the arguments in this paper. According to Wodak (online) "our words are never neutral. They convey how we see ourselves as a profession, our identity, knowledge, values and beliefs and our truths. Our discourse permeates everything we do".

Collaborating this view, McGregor (online) claims that discourse has the capability of making unbalanced power relations and portrayals of social groups to be commonsense, normal, and natural when in actual fact the reality is ideologically loaded. He writes:

Using just words, those in power or wishing to be so can misdirect our concerns for persistent 
large systemic issues of class, gender, age, religion, and culture so that they seem petty or non-existent. Unless we begin to debunk their words, we can be misled and duped into embracing the dominant world view at our expense and their gain. (Online)

This quotation on the potential power of the word in transforming social reality seems to echo the Biblical Isaiah (New International Version, Is. 55:10-11),

Thus says the Lord, "Yet as the rain and the snow come down from heavens do not return without watering the earth, making it yield and giving growth to provide seed for the sower and bread for the eating, so the word that goes from my mouth does not return to me empty, without carrying my will and succeeding in what it was sent to do. (NIV: 666)

J.L Austin's speech act theory recognizes the illocutionary force of utterances which have tremendous social implications (Malmkjaer, 2002: 486-488). As Mey (2001: 301-302) puts it, "words are not just labels we stick on things. The process of wording is based on interaction with our environment... We bespeak the world and the world speaks back at us". These arguments corroborate the fact that speakers' choice of words influences certain meanings and the use of one lexical item instead of another has ideological implications. Political speeches are usually awaited for by the electorate to confirm their expectations for improved conditions of life and sustainable development. Because politicians belong to the category of speakers associated with propaganda, hidden agenda and manipulation of meanings to attain spurious ends (Ezeifeka, 2011), it becomes germane to analyse selected political speeches to decipher whether official meanings conflate with any not too obvious meanings. 
The questions to be addressed in the work include: what thematic choices were made in the speeches with emphasis on the marked and unmarked theme? How have these choices affected the textual meaning of the speeches? What ideological implications do these choices have on the speakers and the audience and on critical language awareness?

\section{Critical Discourse Analysis}

This paper takes the perspectives of critical discourse analysis (CDA), a research paradigm aimed at scrutinizing societal power structures in order to reveal underlying asymmetries, power structures, hidden meanings, linguistic repressions and dominant ideological positions (Fairclough, 1995, van Dijk, 2004, Wodak, 2004, Fowler et al, 1989). Scholars working in CDA also favour the use of systemic functional grammar propounded by Halliday (1985). The focus is on thematic prominence given to some lexical items in subject and topical theme positions since linguistic choices in such positions reflect what the speaker considers important in putting the message across to the audience. In the following section, we shall look at the tenets of systemic functional grammar and thereafter give more insights on the meaning potentials of the textual metafunction realized by the lexicogrammatical feature of Theme and the implications of these choices to critical language awareness.

\section{Systemic Functional Grammar (SFG)}

The systemic functional theory has been recognized by many scholars working in the area of CDA as a powerful explanatory and evaluative framework for analyzing language use in context. This framework sees discourse -language use in speech and writing -as a strategic meaning-making and text-forming resource which enables people to accomplish their purposes in life, make sense of their experiences in the world and act out their personal and group relationships 
(Halliday and Matthiessen, 2004: 29-30). The fundamental concept of the theory is that "language is part of the social semiotic" (Halliday, 1978: 2) -a resource for the social man/woman for making meaning by choosing and this meaning resides in specific contexts and in the systemic patterns of choice of linguistic items.

The concept, 'systemic-functional' therefore derives from these twin attributes of language; on the one hand as systemic, because it comprises a network of potential alternative choices, and on the other, as functional because the actual choices we eventually make out of the totality and the rich inventory of the options open to us in the linguistic system will have a function to perform in our lives. The concept of 'meaning' is essentially the basic component of systemic theory. This meaning -making resource helps language users to make sense of their experiences in their social environment and also act out their social roles and relationships. Halliday (1978: 29) identified three 'meaning potentials' which language conveys simultaneously in the grammar of the clause and referred to them as 'metafunctions' $\mathrm{He}$ calls these metafunctions 'the formalized meaning potential of language' or 'the functional components of the grammar'. These include: the ideational, the interpersonal and the textual metafunctions.

The ideational and interpersonal metafunctions are realized in the grammar of the clause by the Transitivity and Mood systems of the lexicogrammar which I have treated elsewhere (Ezeifeka, 2013, 2014). Our focus in this paper is on the textual metafunction, realized in the Theme structure of the clause. The textual metafunction realizes the "mode" contextual stratum and is regarded as 'the speaker's textforming potential', 'the enabling or facilitating function' for the other two meaning potentials. It relates to how text is created, how language relates to itself (cohesion) and to its 
context of use (coherence) and how the interaction of cohesion and coherence creates texture (Eggins, 2004: 23). It helps to build up meaningful sequences of discourse and discursive flow in relation to the wider context of culture. Halliday and Matthiessen (2004: 64ff) referred to this metafunction as the grammar of the clause as message. Speakers and writers thus exploit this creative potential to achieve a variety of semantic and ideological ends. In this paper, we are limiting our discussion to the analysis of the thematic structure of the selected inaugural political speeches.

\section{Theme/Thematic Structure}

The thematic structure is that structure of the clause that gives it the character of a message. It has two distinct parts: THEME and RHEME (Halliday and Matthiessen, 2004: 66-67). The thematic structure also encompasses "The Given" and "the New" information structure, patterns of foregrounding and backgrounding of information, cohesion and continuity in the organization of the clause (Halliday and Matthiessen, 2004: 30). Halliday and Matthiessen opine that the "Theme/Rheme" structure also in most cases correspond to the "Given/New" information structure $(2004: 93,580)$ but whereas Theme/Rheme structure is speaker-oriented, that is, what the speaker chooses to take as his/her point of departure or embarkation in the clause; "Given/New" information structure is listener-oriented - that is, what information the listener already knows (his/her background knowledge) or have access to and as such should be taken for-granted. However, both Theme/Rheme and Given/New information structure are speaker-selected. The speaker can exploit discretionary potentials open to him/her by the system network of the grammar and the context of situation to achieve and produce an astonishing variety of rhetorical effects to his own gain and at the detriment of the audience. 
The Theme is identified in the grammar of the clause as the first element that carries experiential function (Halliday and Matthiessen, 2004: 79). This is called the topical Theme. The Theme structure of the clause must therefore contain any of a participant, a process or a circumstance and may be preceded or followed by other elements in the thematic structure which are either textual or interpersonal in function and play no part in the experiential meaning of the clause. Halliday and Matthiessen assert that "every clause must contain one and only one topical Theme", Thus in a situation where the initial elements in the clause are interpersonal or textual Theme, a topical Theme must be identified as part of the Theme because it is the element that carries the experiential weight of the clause. Once the topical Theme is identified, the rest of the elements are then consigned to the Rheme role.

Thus when an element to which Transitivity function can be assigned occurs in initial position in the clause, it is called the topical Theme. Clauses usually begin with topical Themes but in some cases the writer/speaker may in addition to topical themes, choose other elements that serve either interpersonal or textual function in the thematic position.

Interpersonal Theme obtains when an element that can be assigned a Mood label occurs in clause-initial position. These include the categories of modal Adjuncts: Modal operators, Vocatives, comment Adjuncts and the unfused finite operators such as in the following examples:

Mood Adjuncts - I think, maybe, just

Vocatives - Fellow Nigerians, we have come today...

Comment Adjunct - Surely, we have come a long way

Unfused finite operator - (Do) know that the elections are over

Textual Theme: These can also occur in clause-initial positions as Theme to perform cohesive function in relating 
the clause to its linguistic and extralinguistic context. These may include continuity adjuncts such as "well", "yea", "oh"; conjunctions such as "so", "but", "and"; conjunctive adjuncts such as "while", "because", "since". It should be noted that interpersonal and textual themes cannot function as theme in isolation of the topical theme. Where a clause has a sequence of elements in the Theme slot, that is, one topical theme and a sequence of other textual and interpersonal elements, then a multiple Theme is the result.

\section{Marked and Unmarked Theme}

Theme may be marked or unmarked. According to Eggins (2004: 318) the term 'unmarked' simply means 'typical/usual' while 'marked' means "atypical/unusual". When an unmarked Theme choice is made, the speaker is assuming that everything is normal. But when a marked choice is made, he/she is signaling that all things are not equal. A marked Theme could be any of the following occurring in Theme position:

- An adverbial group - today, suddenly, somewhat distractedly.

- A prepositional phrase functioning as Adjunct: at night, in the corner, without any warning.

- A Complement - (the least likely such as);

This we must do

You I blame for this (Halliday and Matthiessen,2004: 73)

An unmarked Theme occurs when the topical Theme occupies its rightful position as the grammatical/ logical Subject of the clause as in:

John gave her tea in the morning

"John" is the unmarked theme of the above clause because it is also the Subject.

But if the above clause is reorganized as follows

In the morning John gave her tea. 
"In the morning" becomes the marked topical Theme because it is an experiential element - a circumstantial Adjunct. John is consigned to the Rheme because we cannot have more than one topical Theme in a clause.

Eggins went on to say that Theme markedness has to do with the relationship between the Mood and the Theme structures of the clause, how the functional roles assigned to constituents in a Theme analysis conflate or agree with the functional roles assigned to those same constituents in the Mood Structure and these Mood constituents must have experiential meaning. Examples:

John is coming over - Theme as Subject/declarative Mood Did he come eventually? - Theme as Finite/polar interrogative Mood

When did he come? - Theme as Wh- element/Whinterrogative Mood

Come with me - Theme as Predicator/imperative Mood

The choice of marked Theme in texts is to add emphasis and coherence to the text. The Theme system offers us choices about what to give prominence, what to present as familiar (given) and what to present as unfamiliar (new). The textual metafunction is in fact what makes the experiential and interpersonal meanings of a text to hang together and make sense. It is therefore regarded as the 'enabling function' skilful and appropriate use of thematic selection results in a text which hangs together and makes sense, that is, a text that cohesive and coherent both in its genre and register.

In thematic analysis therefore, we are concerned with the following choices (Eggins, 2004: 321-326): what kinds of Theme get used, choice of topical Theme, and markedness of Theme choices. We shall concentrate on what is taken as given and new, and what is given prominence in the form of 'topicalization' and 'late news'. According to Halliday and 
Matthiessen (2004: 296), prominence in the message means functioning either as 'marked Theme' that is topicalising elements that are not grammatical Subjects, or 'late news' that is, elements that occur after some other participant, or circumstance that already follows the Subject. In other words prominence comes from occurring either earlier or later than expected in the clause

\section{Methodology}

Two political speeches by two Nigerian past leaders: President Olusegun Obasanjo's inaugural speech, "the New Dawn" in 1999 (henceforth Speech 1) and President Shehu Shagari's inaugural speech in 1979 (henceforth Speech 2). These speeches were chosen because they were delivered by two civilian presidents who came immediately after two dictatorial and repressive military regimes, and Nigerians looked upon them as "the messiahs that will bring men and women out of darkness" The two political speeches were divided into clauses using double slash to mark off clause boundaries. A total of 178 and 161 clauses were selected from speeches 1 and 2 respectively. The clauses selected were mostly those that concern the promises made to the electorate, while those that concern foreign policy and those that were considered as repetition of previous ideas were not selected. However, because systemic functional analysis in its comprehensive application involve too many facets and produce too much data, we opted for "selective text analysis" a pragmatic approach to the application of SFL (Eggins, 2004: 331). According to Eggins, a comprehensive application of SFL analysis would involve the following complex dimensions:

- From "above": the contextual stratum of genre and register analysis.

- From "around", the transgrammatical system of cohesion and coherence. 
- From "below", grammatical patterns at clause rank Transitivity, Mood, Theme, logico-semantic relations of clause complex and at group rank - structure of nominal, verbal, adverbial groups and prepositional phrases.

Such an exhaustive analysis would demand considerable time and effort; it would also produce information which may not relate to the focus of the study. A selective approach is therefore necessary so as to apply the SFL analysis to the aspects of our textual data that are found to be "at risk", that is, that would yield the results that are pertinent to the study. Van Dijk (99) also endorses the above assertion by adding that a complete discourse analysis is an illusion. We therefore focus on the pattern of topicalization of certain lexical items as Theme, the foregrounding of certain information as "given" or their backgrounding as "late news". We shall also focus on the implication of markedness in the choice of Theme.

\section{Data Analysis}

The following table presents a summary of the thematic structure of the selected clauses in the speeches under study.

\section{Table 1}

Summary of the Thematic Structure of the Speeches

\begin{tabular}{|l|l|l|c|}
\hline Theme Type & Subtypes & \multicolumn{2}{|l|}{$\begin{array}{l}\text { Occurrence in the } \\
\text { Speeches }\end{array}$} \\
\hline & & Speech 1 & Speech 2 \\
\hline Topical Theme & Unmarked & 152 & 130 \\
(Experiential) & Marked & 26 & 31 \\
& Total & $\mathbf{1 7 8}$ & $\mathbf{1 6 1}$ \\
\hline \multicolumn{4}{|c}{30} \\
\hline
\end{tabular}




\begin{tabular}{|l|l|l|c|}
\hline Interpersonal & Vocatives & 3 & 4 \\
Theme & Comment & 10 & 4 \\
& Modal & 6 & 6 \\
& Adjunct & $\mathbf{1 9}$ & $\mathbf{1 4}$ \\
& Total & & \\
\hline Textual Theme & Conjunction/ & 44 & 33 \\
& Conjunctive & 1 & 11 \\
& Adjuncts & $\mathbf{4 5}$ & $\mathbf{4 4}$ \\
& Total & & \\
\hline
\end{tabular}

Topical Themes are the message-carrying elements in the clause - the one containing the experiential content, the point of embarkation of the message, the "given" information structure. It is therefore our point of focus in the analysis of Theme here. Interpersonal and textual themes are deemphasized since they carry no experiential content.

The first linguistic choice that is of interest in this discussion is choice of personal pronouns as Theme. These choices are represented in the table below:

\section{Table 2}

Summary of Personal Pronouns in Topical Theme/Subject Structure of the Speeches

\begin{tabular}{|l|l|l|}
\hline \multicolumn{1}{|c|}{$\begin{array}{c}\text { Personal Pronoun as } \\
\text { Theme/Subject }\end{array}$} & \multicolumn{2}{|c|}{ Occurrence on the Speeches } \\
\hline $\begin{array}{l}\text { "Speaker" (I, my } \\
\text { government/administration }\end{array}$ & 23 & Speech 1 \\
\hline $\begin{array}{l}\text { "Speaker+" (we, our } \\
\text { government/administration 2 } \\
\text { ) }\end{array}$ & 16 & 18 \\
\hline "addressee" (you) & 3 & 33 \\
\hline
\end{tabular}




\begin{tabular}{|l|l|l|}
\hline $\begin{array}{l}\text { Non interactant subjects } \\
\text { (others) }\end{array}$ & 136 & 106 \\
\hline Total & $\mathbf{1 7 8}$ & $\mathbf{1 6 1}$ \\
\hline
\end{tabular}

As we can see from the above table, some thematized first person personal pronouns are presented as involving only the speaker (I) or the speaker plus others (we). The same is true of such expressions as "my/our administration, my/our government". The reasons behind which one is chosen at a particular point and not the other is seen as deliberate and meaningful. The few instances of the reference to the addressee (you) is also semantically significant in the speeches.

\section{Text 1}

\section{Speech 1:}

a. //You the good people of Nigeria elected me, a man who had walked through the valley of the shadow of death, as your President, to head a democratic civilian administration//

b. //I know what great things// you expect of me at this New Dawn//

c. //As I have said many times in my extensive travels/ in the country//I am not a miracle worker//

d. //Alone I can do little//

e. //You have been asked many times in the past to make sacrifices and to be patient//

f. //I am also going to ask you to make sacrifices and to exercise patience//

g. /Nith God as our guide, and with 120 million Nigerians working with me, with commitment, sustained effort and determination//we shall not fail// 
h. //We shall be firm with them (beneficiaries of corruption)//

i. //We shall restore military cooperation and exchanges with our traditional friends.

j. //And we will help the military to help itself//

$\mathrm{k}$. //that we must change our ways of governance and of doing business on this eve of the coming millennium//.

1. //This we must do/ to ensure progress, justice, harmony and unity//

\section{Speech 2:}

a. //I have formally assumed office as your first executive president//

b. //I want to take this opportunity/ to thank all of you for your patience and support/ throughout the period of transition//

c. //We are assuming office as a result of a free, democratic and peaceful election//.

d. //We must be proud of this//.

e. //and we must be grateful to God//

f. //And it is our determination to do our utmost to contribute to their solution//

g. //We are determined// to transform Nigeria agriculture//

h. //Good shelter is recognized by our government as the right of every Nigerian//

i. //My administration is irrevocably committed to making education a priority//

j. //Our government is determined to release the creative energies of enterprising Nigerians//

Having considered the occurrence of the speaker (I), speaker+ (we) and addressee (you) in subject positions and bearing in mind that the unmarked theme of a declarative clause is its Subject, we shall in this section focus on some 
non-interactant Subjects which were positioned as topical Theme and as marked Theme. The ideological positions of the topicalized Subjects are also indicated.

1. Samples of topicalized non-interactant subjects and marked Theme representing the ills of past administration - positive self and negative other presentation.

(Note: marked Theme - italicized, topical Theme/Subject - bold)

\section{Text 2}

\section{Speech 1}

a. Instead of progress and development which we are entitled to expect from those who governed us, we experienced in the last decade and half .. persistent deterioration in the quality of our governance

b. Government and all its agencies became thoroughly corrupt and reckless.

c. Our infrastructure - NEPA, NITEL, Roads ...were allowed to decay and collapse.

d. One of the greatest tragedies of military rule in recent times is that corruption was allowed to grow unchallenged and unchecked even when it was glaring for everybody to see.

e. The rule and regulation for doing official business were deliberately ignored, set aside or by passed to facilitate corrupt practices.

\section{Speech 2}

a. The problems of creating a national government, a viable economic base and the integration of the various ethnic group... overwhelmed the First Republic.

b. These problems are still with us. 
The speakers topicalized issues which present their predecessors as bad administrators thereby enabling them to present themselves as the saviour of the people.

2. Samples of topicalized non-interactant subjects and marked theme representing the yearning of the

\section{Text 3}

$$
\text { people (propaganda): }
$$

\section{Speech 1}

a. Corruption, the greatest single bane of our society today will be tackled head on at all levels.

b. No society can achieve anything near its full potential if it allows corruption to become the full blown cancer it has become in Nigeria.

c. There will be no sacred cows

d. With God as our guide, and with 120 million Nigerians working with me with commitment, sustained effort and determination, we shall not fail.

\section{Speech 2}

a. Good shelter is recognized by our government as the right of every Nigerian.

b. New emphasis will be placed on modern methods of food storage, distribution and processing.

c. Continuous research will be undertaken and factories will be established for the local manufacture of durable and low cost building materials.

d. Education is our next priority programme.

In the above samples, choices in topical themes involve positioning those social issues which every Nigerian fervently desires clause-initially to give them prominence. 
They are presented as "given", as issues which are taken forgranted, as "fait accompli"

3. Samples of marked Themes and late news representing evasion, propaganda and misrepresentation of facts. Features of marked themes (placed clause-initially) and late news (placed clause-finally) are represented by circumstantial Adjuncts - an experiential element, (in italics).

\section{Marked Theme}

Text 4

\section{Speech 1}

a. Before any issues are introduced to the cabinet, the time tested procedures of interministerial consultation would have to be made.

b. As a retired officer, my heart bleeds to see the degradation in the proficiency of the military.

c. In our difficult and abnormal situation, great care and circumspection are called for in appointment to the cabinet and high public positions.

\section{Speech 2}

a. As we develop our economy, we shall be in a better position to provide the needed services and amenities for all our citizens. We shall then be better equipped to improve our health and other social services programme for the nation.

b. With the swearing in ceremony this morning, I have formally assumed office as your first executive president. 
c. Because of the importance we attach to housing, we shall establish a Ministry of Housing and Environments.

d. In the urban areas, we will immediately create new layouts to be serviced by adequate drainage system, roads and other infrastructure.

e. In the rural areas and small towns, the establishment of Rural Housing Corporation will be encouraged.

\section{Late news (usually in Rheme Position)}

\section{Text 5}

\section{Speech 1}

a. We give praise and honour to God for this day specially appointed by God Himself.

b. I wish to pay tribute to the great and gallant Nigerians who lost their lives in the cause of the struggle for liberty, democracy and good governance.

c. I believe that this administration must deal with the following issues even in these difficult times of near economic collapse.

\section{Speech 2}

We are assuming office as a result of a free, democratic and peaceful election.

These issues which were foregrounded or backgrounded in these samples range from promises which implementation is doubtful, to claims which were mere distortion of facts, to evasion of the proposition using circumstances of condition or frustrated cause.

\section{Discussion}


It is a known fact that the unmarked Theme of a declarative clause is its Subject (Halliday and Matthiessen, 2004). The use of personal pronouns (I, we, you), and possessive (my government/administration, our government/administration) in potential Subject positions is seen as ideologically motivated. The choice of Subject by a speaker is guided by two considerations. Firstly, a speaker chooses as Subject that linguistic element which they would want to assign modal responsibility and secondly, that item which they want to make prominent as Theme, and which they are calling on the listener to acknowledge and verify.

The two speeches show a preponderance of a deliberate oscillation in the use of "I" and "we", "my" and "our" in potential Subject and topical Theme positions. This shift could be interpreted as deliberate manipulation by the speakers aimed at either claiming or disclaiming responsibility depending on the issue at stake. It seems that "we" is used when the speaker is in doubt of the verifiability or acceptability of the proposition or proposal. If the proposition/proposal fails, the speaker would not be held modally responsible for the claim. On the other hand, "I" is used when the speaker is on safer grounds and wants to claim responsibility for positive achievement. This is to support the assertion by Jones and Wareing (46) on the implication of the shift in the use of personal pronouns - either to take credit for positive achievement or to disguise responsibility. Yet another explanation to the shift in the use of singular and plural personal pronouns in Subject position could be that "we" is used when the speakers want to adopt a "face-preserving act" (Yule, 1996: 61 ), when they need the solidarity of their audience, to identify with them as "in-group" and thus win their consent and perpetuate their hegemonies. In that case, the asymmetry in power is attenuated by the use of inclusive "we". However when the speakers want to assert authority as 
one in control, they change to face-threatening acts by the use of singular "I" meaning "I am in charge here"

Bloor and Bloor (2004: 228) also claim that the grammatical use of possessive pronouns (my/our) in conjunction with nominals representing things that in fact cannot be owned in any real sense of the word is ideological. For instance, such expressions as "my government/administration" "our government/administration", "our country", "our people" - which are replete in the two speeches - can colour people's attitudes to the world, and in addition to encouraging traditional loyalty, care and other natural emotions, can also distort the ugly side of issues making them more acceptable and thus divert the audience attention from any hidden agenda. The speeches made such appeals to the emotion of Nigerians that little attention was paid at the time to how most, if not all of the lofty and appealing proposals could be actualized.

The use of "you" and some instances of "we" in Subject positions in the speeches tend to invest the burden of modal responsibility on the addressee (Nigerians) even when the speech-functional import of such propositions are questionable. For instance in the following sample text (Text 1, Speech 1, Number a)

//You the good people of Nigeria elected me, a man who had walked through the valley of the shadow of death, as your President, to head a democratic civilian administration//

Few Nigerians would wholly subscribe to this representation of the electoral process referred to by the speakers but because this represents the written "truth" of the dominant ideology, no consideration was given to the unwritten, muted skepticism of Nigeria's teeming millions as to the veracity of the above assertions. 
Data from Table 1 were used to find out what linguistic features were topicalized/thematized and how these projected the meaning of "given" and "new" information structure in the speeches. Our findings show that certain lexical items which represent the yearnings of the people and the ills of past administration were presented as topical Theme while topical Theme referring to the weaknesses of the speakers were deemphasized or non-existent. The yearnings and expectations of the people were presented in catchy lexicalizations in topical Theme positions as "given". Such lexical items and phrases as "corruption", "good shelter" free education" "home ownership" "our infrastructure". "wage freeze issue," "the question of car loans" "labour independence" "free collective bargaining" "food supply", "food security and agriculture" poverty alleviation" "job creation" among others were fronted in a manner that make the audience take the implementation of these proposals forgranted as fait accompli. Yet to date, the fulfilment of these promises has remained an illusion, a mirage, and a utopia. Nigeria is still reportedly wallowing in corruption especially among politicians and public officers. Good shelter, good food and employment opportunities still elude the average Nigerian especially school leavers. The majority of Nigerians still live in abject poverty in spite of these proposals. Our infrastructure - NEPA (now Power Holdings Ltd), roads, railways, education, housing are still in a state of decay and disrepair more than three decades after Speech 2 and one decade after Speech 1. Only the debt issue - that is, clearing Nigeria's huge foreign debt and improved wages of some category of workers promised in Speech I were actualized during the tenure and these earned that regime a lot of credibility. Not many of the promises in speech 2 were realized at the expiration of the regime. It was "business as usual" as governance had remained corrupt even during the two regimes 
under study. The above assertions therefore call to question the genuineness of these two speakers, how true they were to their promises. We therefore conclude that these speeches were instruments of political fantasy (Charteris-Black, 2004), creating illusions while perpetuating hegemonic regimes.

Similarly, thematic prominence was achieved in the speeches by the use made of marked Theme. Marked Theme occurs in a clause when what is placed clause-initially is not the logical Subject of the clause but an experiential element mostly a circumstantial element. In the speeches, the majority of marked Themes were circumstantial elements. Samples of these are presented in Text 2, as in for instance

As we develop our economy, we shall be in a better position to provide the needed services and amenities for all our citizens.

Prominence was also achieved in the speeches by what Halliday and Matthiessen (2004: 296) referred to as "late news" - elements that occur after some other participant or circumstance that already follows the Subject. For instance, in the speeches, the underlined phrases were presented as late news even when they represented the hinge on which the messages revolve.

...this administration will deal with the following issues even in this period of near economic collapse.

We give praise and honour to God for this day specially appointed by God Himself.

We are assuming office as a result of free, democratic and peaceful election.

Topicalizing elements that are not grammatical Subjects or presenting them as late news are means of foregrounding and backgrounding of information which the speakers exploited. Issues that were thus presented in the speeches range from promises which implementation were doubtful, to claims which tend towards masking real meanings, evasions and propaganda. 


\section{Conclusion}

In this paper, an attempt has been made to analyze two inaugural speeches and how the speakers' choices in topical theme positions affect meanings. It is seen that speakers make discreet choices of what they want to make prominent and what they want to deemphasize as late news. It is seen that texts convey more than the words used in them not so much because of their semantic load but because of the way they are positioned in the grammar of the clause. Proper reading of texts is therefore advised, to be able to sift official meanings from other hidden meanings occasioned by how the message is packaged. This is necessary for critical language awareness which CDA is all about.

\section{Funding Acknowledgement}

The manuscript for this publication was prepared with the support of an African Humanities Program (AHP) Fellowship, established by the American Council of Learned Societies (ACLS) and supported financially by the Carnegie Corporation of New York.

\section{Chinwe R. Ezeifeka}

Department of English Language and Literature

Nnamdi Azikiwe University Awka, Nigeria

\section{References}

Bloor, T. \& Bloor, M. (2004) The Functional Analysis of English: A Hallidayan Approach. $2^{\text {nd }}$ ed. London: Hodder Education.

Bloor, M \& Bloor, T. (2007) The Practice of Critical Discourse Analysis: An Introduction London: Hodder Arnold. 
Robinson, M. (ed.) (2007) Chambers $21^{\text {st }}$ Century Dictionary. Revised ed.. New Delhi: Allied Chambers Ltd.

Crystal, D. (1995). The Cambridge Encyclopedia of the English Language. Cambridge: Cambridge University Press.

Crystal, D. (2003). A Dictionary of Linguistics and Phonetics. $5^{\text {th }}$ ed. Malden: Blackwell.

Carlin, P.D. \&Payne, J.(1995). Public Speaking Today. $2^{\text {nd }}$ ed. Chicago: National Textbook Company.

Dawodu.com. "Shagari's Inaugural Address to Nigerians" October, http://www.dawodu.com/shag/htm. accessed 11/05/09.

Ebest S. B.; Alred, G.J; Brusaw, C.T.; \& Oliu, W.E.(2003). Writing from A-Z The-Easy-to Use Reference Handbook. 4th ed. Boston: McGraw Hill Co.

Eggins, S. (2004) An Introduction to Systemic Functional Linguistics. $2^{\text {nd }}$ ed. New York: Continuum.

Ezeifeka, C.R. (2013). Analysis of experiential meaning in selected inaugural political speeches in Nigeria. An International Journal of Language, Literature and Gender Studies. Vol 2(1). Pp. 170-190.

Ezeifeka, C.R. (2013). Critical discourse analysis of interpersonal meaning and power relations in 
selected inaugural political speeches in Nigeria. UNIZIK Journal of Arts and Humanitie. Vol 14(2). Pp 46-65

Fairclough, N. (1995) Critical Discourse Analysis: The Critical Study of Language. Essex: Longman: Group Ltd.

Fairclough, N. (2002) Critical linguistics/critical discourse analysis. The Linguistic Encyclopedia. $2^{\text {nd }}$ ed. Malmkjaer, K (ed). London: Routledge, 102106.

Fairclough, N. (1999). Global capitalism and critical awareness of language". Language Awareness.Vol.8(2). http://www.multilingualmatters.net/1a/008/0071/1a008007/1pdf. Accessed 30/7/08.

Fairclough, N. (1996). Rhetoric and critical discourse analysis: A reply to Titus Ensink and Christoph Sauer" Current Issues in Language and Society. Vol 5(3). 286-289.

Halliday, M. A.K. (1973) Explorations in the Functions of Language. London: Edward Arnold (Publishers) Ltd.

Halliday M.A.K. (1978). Language as Social Semiotic. The Social Interpretation of Language and Meaning. London: Edward Arnold.

Halliday, M A.K and Hasan, R. (1976). Cohesion in English. London: Longman. 
Halliday, M.A.K. \& Matthiessen, C. M. M. (2004). An Introduction to Functional Grammar. $3^{\text {rd }}$ ed. London: Hodder Arnold.

Jones, J. \& Wareing, S. (2000). Language and politics. Language, Society and Power, An Introduction. Linda T. \& Wareing, S. (eds.) London: Routledge, 31- 47.

Malmkjaer, K. (2002) The Linguistic Encyclopedia. $2^{\text {nd }}$ ed. London: Routledge.

Mazrui, A. A. (1975) The Political Sociology of the English Language: An African Perspective. The Netherlands: Mouton and Co.

McGregor, S. L. T. Critical Discourse Analysis: A Primer. Online http://www.kon.org/archives/forum/151/mcgregorcda.html, accessed 18/02/08.

Mey, J. L. (2001) Pragmatics: An Introduction. Malden, MA: Blackwell.

Nigeria World Publication. "Inaugural Speech by His Excellency, President Olusegun Obasanjo following his Swearing-in as President of the Federal Republic of Nigeria on May 29, 1999" http://nigeriaworld.com/feature/speech inaugural. Accessed 11/05/09 .

Osuntokun, A. \& Aworawo, D. (2003) A new dawn? Nigerian politics since 1999 . Issues in Nigerian Government and Politics. Akinjide, $\mathrm{O}$ et al. 
(eds.) Ibadan: Rex Charles Publications, 250260.

The Holy Bible New International Version. (1984). Colorado: International Bible Society.

Van Dijk, T. A. (2005). Multidisciplinary CDA: A plea for diversity". Methods of Critical Discourse Analysis. Wodak, R. \& Meyer, M. (eds.). London: Sage. 95-120.

Wardhaugh, Ronald. (2006). Introduction to Sociolinguistics. $5^{\text {th }}$ ed. Malden, MA: Blackwell Publishing.

Wodak,

R. Critical discourse analysis' $<\mathrm{http} / \mathrm{www}$.qualitativereserach.net/fgs-texts-207/07-2-29e.htm? accessed 19/2/08.

Wodak, R. (2005). The discourse-historical approach. Methods of Critical Discourse Analysis. Wodak, R.\& Meyer, M. (eds). London: Sage. 63-94.

Wodak, R. \& Busch, B. (2004). Approaches to media texts. Handbook of Media Studies. Downing, J. et al. (eds.) London: Sage, 105-123.

Yule, G. (1996). Pragmatics. Oxford: Oxford University Press.

Yule, G. (1985). The Study of Language. Cambridge: Cambridge University Press. 